\title{
Przyczynek do badań nad ramą wydawniczą utworów dramatycznych Wincentego Ignacego Marewicza ${ }^{* *}$
}

Wincenty Ignacy Marewicz - pisarz okresu polskiego oświecenia, poeta, komediopisarz, publicysta. Urodził się w 1755 roku na Litwie, w województwie trockim, syn Bazylego Antoniego herbu Kościesza. Uczył się w szkołach jezuickich w Wilnie, lecz jego edukacja była skromna, i to nie tylko z powodu niedostatku, z którym borykała się rodzina pisarza. Kierowany bowiem chęcią ,usunięcia się od zbytecznej zwierzchników szkolnych srogości"", Marewicz często uciekał ze szkół i w rezultacie swoją naukę zakończył na klasie gramatyki. Po 1776 roku rozpoczął bez wyraźniejszego zamiaru kilkuletnie podróżowanie po kraju. Przebywał w Płocku, Grodnie, Wilnie, Krakowie. Jako rzecznik ustrojowych i społecznych reform aktywnie działał na polu publicystyki towarzyszącej obradom Sejmu Czteroletniego. Przy finansowej pomocy księcia Macieja Radziwiłła zakupił w 1791 roku domek w Wilnie, gdzie zamieszkał. Tam też został wybrany na urzędnika municypalnego. Podczas powstania kościuszkowskiego zaciągnął się wraz z żoną (osobą bliżej nieznaną) do wojska na „prostych żołnierzy”. Pod koniec 1798 roku przebywał we Lwowie. Po 1800 roku mieszkał już w Warszawie, był urzędnikiem Stanu Cywilnego i członkiem łoży wolnomularskiej Świątynia Izis. Zmarł 5 marca 1822 roku w Warszawie².

* Dr, Uniwersytet Łódzki, Wydział Filologiczny, Instytut Filologii Polskiej, Katedra Edytorstwa, ul. Pomorska 171/173,91-404 Łódź; e-mail: anna_petlak@interia.pl

** Publikacja prezentuje wyniki badań, finansowanych przez Narodowe Centrum Nauki na podstawie decyzji nr DEC-2011/01/D/HS2/02852.

${ }^{1}$ W. I. Marewicz, Ostatnia do Laury odezwa wierszem i proza, Drukarnia Misjonarzy, Warszawa 1788 , s. 2.

${ }^{2}$ Biogram W. I. Marewicza opracowano na podstawie: E. Tyszkiewicz, Wincenty Marewicz, „Gazeta Warszawska” 1870, nr 61, s. 3-4; nr 62, s. 3; nr 63, s. 3; E. Aleksandrowska, Wincenty Ignacy Marewicz (1755-1822), w: Pisarze polskiego oświecenia, pod red. T. Kostkiewiczowej i Z. Golińskiego, t. 2, Państwowe Wydawnictwo Naukowe, Warszawa 1994. s. 332-341. Pomocne były także następujące publikacje: E. Aleksandrowska, Marewicz Wincenty Ignacy (1755-1822), w: Dawni pisarze polscy od początków piśmiennictwa do Młodej Polski. Przewodnik biograficzny i bibliograficzny, red. działu Literatura oświecenia: E. Aleksandrowska, koordynator całości: R. Loth, t. II (I-Me), Wydawnictwa Szkolne i Pedagogiczne, Warszawa 2001, s. 427-429; taż, Marewicz Wincenty Ignacy, w: Polski słownik biograficzny, t. XIX, Zakład Narodowy im. Ossolińskich - 
Jako pierwszy postacią Marewicza zajął się Eustachy Tyszkiewicz, który jest autorem rozprawy Wincenty Marewicz. Studium obyczajowe, opublikowanej w 1870 roku $^{3}$. Ostatniego najszerszego opracowania biograficznej i literackiej sylwetki pisarza (łącznie z edycją kilku jego wierszy) dokonała Elżbieta Aleksandrowska w tomie drugim pracy zbiorowej Pisarze polskiego oświecenia ${ }^{4}$. Publikację tę poprzedziły inne prace tej badaczki, między innymi w Polskim słowniku biograficznym i w słowniku biobibliograficznym Dawni pisarze polscy ${ }^{5}$. W innych pracach literaturoznawczych, omawiających problemy literatury oświecenia, pojawiają się przeważnie krótkie wzmianki dotyczące tego autora ${ }^{6}$, czemu towarzyszyły niekiedy edycje jego pojedynczych tekstów ${ }^{7}$. Szerszym ujęciem cechuje się rozprawa na temat wątków miłosnych w utworach Marewicza ${ }^{8}$. Co ciekawe, jeden $\mathrm{z}$ utworów pisarza (Zdarzenia czyli sny ... ${ }^{9}$ ) w kontekście początków prozy preromantycznej zainteresował Aleksandra Lipatowa ${ }^{10}$. Utwór Marewicza zyskał wysoką ocenę rosyjskiego badacza.

Wydawnictwo Polskiej Akademii Nauk, Wrocław-Warszawa-Kraków-Gdańsk 1974, s. 633-636; Bibliografia literatury polskiej "Nowy Korbut”, t. V: Oświecenie, oprac. E. Aleksandrowska z zespołem, Państwowy Instytut Wydawniczy, Warszawa, 1966-1972, s. 303-306.

${ }^{3}$ Rozprawa ta przeszła przez druk dwukrotnie, najpierw ukazała się w „Gazecie Warszawskiej” w 1870 roku (nr 61, s. 3-4; nr 62, s. 3; nr 63, s. 3), następnie zaś opublikowano ją w postaci oddzielnej odbitki w drukarni tejże gazety.

${ }^{4}$ Opis tej pozycji zob. przyp. 2.

${ }^{5}$ Zob. przyp. 2.

${ }^{6}$ Zob. m.in.: A. Norkowska, Codzienne zapachy miasta utrwalone w piśmiennictwie polskiego Oświecenia, w: Codzienność i niecodzienność oświeconych, t. II, W rezydencji, w podróży i na scenie publicznej, pod red. B. Mazurkowej, z udziałem M. Marcinkowskiej i S. P. Dąbrowskiego, Wydawnictwo Uniwersytetu Śląskiego, Katowice 2013, s. 115-125, Prace Naukowe Uniwersytetu Śląskiego w Katowicach nr 3072; P. Rysztowski, Jak napisać historię grafomanii, „Teksty Drugie" 2012, nr 6, s. 346-357; D. Ratajczakowa, Komedia oświeconych 1752-1795, Państwowe Wydawnictwo Naukowe, Warszawa 1993; J. Jack1, Litteraria, w: Teatr Narodowy 1765-1794, pod red. J. Kotta, Państwowy Instytut Wydawniczy, Warszawa 1967.

${ }^{7}$ Wiersze imieninowe poetów z drugiej połowy XVIII wieku, wstęp, wybór tekstów i opracowanie B. Wolska, B. Mazurkowa, T. Chachulski, Instytut Badań Literackich PAN Wydawnictwo, Warszawa 2011; Wiersze polityczne Sejmu Czteroletniego, oprac. K. Maksimowicz, cz. 1 (1788-1789), Wydawnictwo Sejmowe, Warszawa 1998; Świat poprawiać - zuchwałe rzemiosło. Antologia poezji polskiego Oświecenia, oprac. T. Kostkiewiczowa, Z. Goliński, Państwowy Instytut Wydawniczy, Warszawa 1981; Cztery wieki fraszki polskiej, wybór i wstęp J. Tuwim, Czytelnik, Warszawa 1957.

${ }^{8}$ Zob. A. Petlak, Miłosne ,odezwy” do Laury Wincentego Ignacego Marewicza, w: Codzienność i niecodzienność oświeconych, t. I, Przyjemności, pasje, upodobania, pod red. B. Mazurkowej, z udziałem M. Marcinkowskiej i S. P. Dąbrowskiego, Wydawnictwo Uniwersytetu Śląskiego, Katowice 2013, s. 191-201, Prace Naukowe Uniwersytetu Śląskiego w Katowicach nr 3072.

${ }^{9}$ W.I. Marewicz, Zdarzenia czyli sny... wierszem i proza, t. 1-2, Drukarnia P. Dufour, Warszawa $1786-1787$.

${ }^{10}$ А.В. Липатов, Начала польской предромантической прозы XVIII в. (Эволючия художественного мышления и внутрижанровые изменения в контексте национального и общеевропейского литературного проиесса), w: Развитие прозаических жанров в литературах стран Центральной и Юго-Восточной Европы, ред. И.И. Калиганов, 
Twórczość literacka Wincentego Ignacego Marewicza jest bogata i różnorodna. W dorobku tego pisarza znajdujemy między innymi pisma wierszem i prozą, okolicznościowe i okazjonalno-towarzyskie, osobiste liryki, pieśni, erotyki, sielanki, bajki, epigramaty, a także utwory dramatyczne ${ }^{11}$. Większość jego dzieł jest poświęcona kobiecie o imieniu Laura bądź w różnym stopniu związana z tą osobą. Laura - do czego przyznaje się sam Marewicz - odrzuciła jego zaloty, ponieważ - jak poeta pisze w wierszu Żadza nierozważna - „wysoko patrzy, a ja nie jestem znamienitym"12. Pisarz nigdy nie wyjawił swoim czytelnikom, kim była owa tajemnicza muza i adresatka jego tekstów. Zgodnie z sugestią Tyszkiewicza ${ }^{13}$, można przypuszczać, iż pod imieniem literackiej Laury została ukryta Barbara Jelska (1740-1821), córka starosty pińskiego, uczennica wileńskich bernardynek. Rzeczywiście nie była to para dla biednego Marewicza, jednego z ówczesnych „chudych literatów” (jak ich określano, w nawiązaniu do satyry Adama Naruszewicza pod tym tytułem ${ }^{14}$ ), czego autor miał pełną świadomość, a o czym świadczy na przykład przywołane wyżej jego wyznanie zawarte w wierszu Żądza nierozważna.

Laurę poeta spotkał w grudniu 1776 roku i zakochał się w niej od pierwszego wejrzenia. Pragnąc wyraziściej wyeksponować swoją miłość, właśnie dla Laury Marewicz w 1783 roku założył w Wilnie amatorski teatr i zadebiutował na scenie swoją sztuką Miłość dla cnoty. Na przedstawienie osobiście zaprosił ukochaną i wszelkimi sposobami starał się pokazać, że całe to przedsięwzięcie zostało

А.П. Соловьева, Б. Ф. Стахеев, Наука, Москва 1991, s. 58-84. Tłumaczenie tego tekstu na język polski pt. Początki polskiej prozy preromantycznej XVIII wieku (Ewolucja myśli artystycznej oraz przemiany gatunkowe na tle narodowego i europejskiego procesu literackiego) ukazało się kilka lat później w „Przeglądzie Humanistycznym” 1998, nr 1, s. 80-102.

${ }^{11}$ Por. E. Aleksandrowska, Wincenty Ignacy Marewicz..., s. 334-335.

${ }^{12}$ W. I. Marewicz, Dorywcze zabawki wierszem i proza, Drukarnia Misjonarzy, Warszawa 1788, s. 93.

${ }^{13}$ Zob. E. Tyszkiewicz, Wincenty Marewicz, nr 62, s. 3.

${ }^{14}$ Satyra ta została opublikowana w 1773 roku w czasopiśmie „Zabawy Przyjemne i Pożyteczne” (zob. E. Aleksandrowska, „Zabawy Przyjemne i Pożyteczne” 1770-1777. Monografia bibliograficzna, Wydawnictwo Instytutu Badań Literackich PAN, Warszawa 1999, s. 124, nr 557). Dość powszechnie w badaniach, dotyczących epoki oświecenia, mianem „chudych literatów” określa się pisarzy, przedstawicieli tworzącej się dopiero warstwy inteligencji twórczej, bez stałej pracy, pozbawionych mecenatu, usiłujących wyżyć z pracy pióra, żyjących w obliczu niedostatku czy zagrażającej im ruiny finansowej w trudnych okresach życia. Temat ten omawiał m.in. Roman Kaleta w szerzej zakrojonym artykule: Miejsce i spoleczna funkcja literatów w okresie Oświecenia, w: Problemy literatury polskiej okresu Oświecenia, red. Z. Goliński, Zakład Narodowy im. Ossolińskich, Wrocław 1973, s. 5-47. Nawiązał tam (s. 34) do znanej satyry Naruszewicza Chudy literat, omawiając narzekania pisarzy żyjących w okresie Oświecenia na niedolę, co było zjawiskiem dość powszechnym, i co - zdaniem badacza - „w literaturze stało się zjawiskiem konwencjonalnym”. Zob. też B. Wolska, Wprowadzenie do lektury oraz Komentarze, w: A. S. Naruszewicz, Poezje zebrane, wyd. B. Wolska, t. III, Wydawnictwo Instytutu Badań Literackich PAN, Warszawa 2012, s. 15; s. 365-373, Biblioteka Pisarzy Polskiego Oświecenia, t. 11. 
zorganizowane i adresowane wyłącznie dla niej. Jednak niewłaściwe zachowanie pisarza aktora sprawiło, że było to jego ostatnie spotkanie z ukochanąa ${ }^{15}$. To zaś w konsekwencji wywołało u niego na jakiś czas zniechęcenie do działalności teatralnej.

Do twórczości dramatycznej oraz do zainteresowania teatrem pisarz powrócił dopiero po dwunastu latach. Sztuki Marewicza były wystawiane na scenie wileńskiej w latach 1795-1798 z aktorskim udziałem autora i jego (nieznanej bliżej) małżonki.

Wincenty Ignacy Marewicz jest autorem trzech komedii: Mitość dla cnoty. Komedia oryginalna w 3 aktach (Warszawa 1787), Miłość wszystkich porównywa. Komedia oryginalna w 5 aktach (Wilno 1796), Wszystko się skończyło na projekcie. Komedia oryginalna we 2 aktach (b.m.w. i r.), ponadto opery Polusia, córka kołodzieja, czyli Wolność oswobodzona. Opera tragiczna w 2 aktach, z rosyjskiego na polski język przettumaczona (edycja 1 - b.m.w. 1789, edycja 2 - Lwów 1791) oraz dwóch dram: Szczęście w nieszczęściu, czyli Wzór stałości ludzkości i cierpliwości. Drama oryginalne w 4 aktach (b.m.w., 1798) i Żona opuszczona na bezludnej wyspie. Drama w 1 akcie, z intrygi wziętej z opery włoskiej (Wilno 1795).

Utwory dramatyczne Marewicza (tak jak i większość tekstów autora) należy rozpatrywać, nawiązując do zagadnienia literackiej ramy wydawniczej, a zatem, jak wskazuje Renarda Ocieczek, z zespołem „elementów piśmienniczych dodanych do tekstu głównego [danego - przyp. A.P.] dzieła, wprowadzających lub zamykających tenże tekst”'16. Mowa tu o tradycji dołączania przez pisarzy do swych

${ }^{15}$ E. Tyszkiewicz opisuje wspomniane działania i zachowanie Marewicza następująco: „Ostatki stracił [Marewicz - przyp. A.P.] na jakie takie urządzenie sceny i miejsc dla publiczności; a kiedy wszystko było gotowe, udał się osobiście do klasztoru dla zaniesienia Laurze biletów i uproszenia, by na pierwszym tym widowisku być raczyła. Młoda panienka, zapewne dla rozrywki wśród klasztornego monotonnego życia, była z ciotką w teatrze. Marewicz spotkał ją i, jak pisze, „usta moje pełne najtęższego ognia w jej rączki wpoiłem”. Wszędzie tego wieczora dawał Laurze poznać, że to widowisko dla niej tylko było urządzone, a co gorsza, że na scenie wszystko co mówił, do niej tylko jednej adresował. Fatalnie nieborak ukartował swoje interesa: bo Laura jako osoba przyzwoita, zrozumiawszy co się święci, nigdy już, chociaż bilety były jej zanoszone, nie była w teatrze. Co większa, odtąd już Marewicza w klasztorze nie przyjmowano, i nigdy więcej w życiu Laury nie widział". Zob. E. Tyszkiewicz, Wincenty Marewicz, nr 62, s. 3.

${ }^{16} \mathrm{R}$. Ocieczek, O różnych aspektach literackiej ramy wydawniczej w książkach dawnych, w: O literackiej ramie wydawniczej w ksiązkach dawnych, pod red. tejże, Wydawnictwo Uniwersytetu Śląskiego, Katowice 1990, s. 7-19. Inne opracowania na temat ramy wydawniczej tejże badaczki: taż, O staropolskich tekstach dedykacyjnych. Uwagi wstępne, w: Dedykacje w książe dawnej $i$ wspótczesnej, red. R. Ocieczek i A. Sitkowa, Wydawnictwo Gnome, Katowice 2006, s. 7-10; taż, Studia o dawnej ksiażce, Wydawnictwo Gnome, Katowice 2002; taż, O przedmowach w polskich książkach barokowych, w: Przedmowa w książce dawnej i wspótczesnej, pod red. tejże, przy współudziale R. Ryby, Wydawnictwo Gnome, Katowice 2002, s. 102-116; taż, hasło: Rama utworu, w: Stownik literatury staropolskiej. (Średniowiecze-Renesans - Barok), red. T. Michałowska przy współudziale B. Otwinowskiej, E. Sarnowskiej-Temeriusz, Zakład Narodowy im. Ossolińskich, Wrocław 1990, s. 684-688. Dużą uwagę zagadnieniu ramy wydawniczej poświęciła Bożena Ma- 
dzieł takich dodatków, jak przedmowy, dedykacje, wiersze dedykacyjne, komentarze, a nawet spisy utworów, indeksy, wykazy prenumeratorów, które - chociaż najczęściej nie mają bezpośredniego związku z tekstem głównym - pełnią ważną funkcję literacką i społeczną oraz są źródłem znaczących informacji (na przykład o powodach lub okolicznościach opublikowania utworu, o programie literackim autora, a niekiedy także o jego sytuacji życiowej). Te „,dodatki” do dzieł niosą zatem istotne treści - nie tylko zewnętrzne, faktograficzne, ale i „wewnątrztekstowe". W tradycję tę wpisuje się duża część utworów Marewicza.

Na kartach tytułowych swoich tomików Marewicz często umieszczał epigrafy, które anonsowały tematykę dzieła. Swoje druki wyposażał pisarz również w „przedmowy do czytelnika” oraz dedykacje różnej objętości (od dwóch nawet do dziesięciu stron), najczęściej pisane prozą z wierszem. Dedykacje te kierował do znanych osób, wysoko postawionych osobistości krajowych, o których względy się upraszał lub za które dziękował. Niekiedy dedykacje skierowane były do osoby mniej znanej, której Marewicz coś zawdzięczał i w ten sposób pragnął podziękować za przysługę. Co ważne, dedykacje i przedmowy dostarczają nam istotnych informacji o samym autorze.

Komedia Miłość dla cnoty została zadedykowana Aleksandrowi Sapieże, kanclerzowi wielkiemu litewskiemu. W zawartym w dedykacji wierszu laudacyjnym Marewicz wysoko ceni wykazywaną przez adresata troskę o dobro ojczyzny oraz cechę charakteru, jaką jest cnota:

Nie dla tego to dzieło daję tobie śmiele,

Żebym go sądził twego oka godnym, panie;

Bo zaszczyty w narodzie, co masz onych wiele,

Chcąc wystawić, możności mej na to nie stanie.

I ponieważ ich zdolnie nie zmogę okréślić,

Nie wolno mnie: jak tylko ze czcią o tym myślić.

zurkowa: taż, Literacka rama wydawnicza dzieł Franciszka Dionizego Kniaźnina (na tle porównawczym), Wydawnictwo Uniwersytetu Śląskiego, Katowice 1993 (tu na s. 7-15 autorka podaje szczegółowy stan badań nad elementami ramowymi książki); taż, ,Weksle prawdy i nieprawdy”. Studia literackie o książce oświeceniowej, Instytut Badań Literackich PAN, Warszawa 2011; taż, O reklamie wydawniczej w przedmowach edytorów i drukarzy polskich doby oświecenia, „Prace Naukowe Uniwersytetu Śląskiego. Studia Bibliograficzne" nr 5, 1992, s. 129-149; taż, Tradycja i nowatorstwo w kształtowaniu literackiej ramy wydawniczej dzieł F.D. Kniaźnina, „Prace Literackie”, seria XXXI, Wrocław 1991, s. 243-259; taż, Przedmowy, dedykacje i noty twórczości F. D. Kniaźnina, w: O literackiej ramie wydawniczej w ksiażkach dawnych, red. R. Ocieczek, Wydawnictwo Uniwersytetu Śląskiego, Katowice 1990, s. 63-98. Problemem elementów ramy wydawniczej zajęli się również: K. Tutak, Dedykacja w świetle genologii lingwistycznej, „LingVaria” 2010, nr 1 (9); s. 125-135; P. Pirecki, Z problematyki ramy literackiej w komediach plebejskich XVII w. (wybrane zagadnienia), „Acta Universitatis Lodziensis. Folia Litteraria Polonica” 2002, nr 5, s. 13-26; A. Borkowski, Konteksty interpretacyjne literackiej ramy wydawniczej „Ogrodu nie plewionego” Wacława Potockiego, „Slavica Litteraria” 13, 2010, nr 1-2, s. 63-72. 
Wielkim jesteś z honorów, i wielkim z imienia,

Wielkim z dzielnej mądrości, lecz największym z cnoty

I z pilnego o dobro krajowe baczenia.

Wielkiś zatem z pozoru i wielkiś $\mathrm{z}$ istoty,

I że cię za wielkiego każdy człek uznaje -

Przeto ja, będąc małym, ten hołd tobie daję ${ }^{17}$.

Dalej poeta wprowadza wątki mniej oficjalne. Sygnalizuje podobieństwo tytułu swojej komedii, w którym ujął miłość i cnotę, z decyzją, jaką podjął adresat owej dedykacji, wybierając mężów dla własnych córek. Zaakcentował to zarówno w cząstce o charakterze wypowiedzi epistolograficznej, kierowanej do księcia, jak i w dołączonym doń czterowierszu, w formie myśli o charakterze uniwersalnym:

Wasza księcia mość dobrodziej zaś, dając pierwszeństwo cnocie i rozumowi przed bogactwem i okazałością z starających się o córki jego, wznowiłeś zwyczaj dawny przodków naszych, wpajając w ich umysł następne zdanie:

Zdrowiej balsam wypić z gliny,

Niźli truciznę ze złota.

Człeka albowiem jedyny

Rozum umacnia i $\operatorname{cnota}^{18}$.

Dedykacja ta w pośredni sposób nawiązuje do nieszczęśliwej miłości Marewicza, ale także i do treści samej komedii. Pisarz nie szczędzi pochwał dla córek Sapiehy, które, mając na względzie mądrą radę ojca, „tym tylko towarzyszyć ofiarowały się, których osobiste przymioty godnymi tego szczęścia czyniły"19. Ponadto jest pewien, że takim właśnie zachowaniem i sposobem myślenia córki stały się wzorem do naśladowania dla innych dam, o których potomkowie powiedzą:

Że nie fraczkiem, perfumą, nie pudrem, nie złotem,

Nie trzpiotalstwem, podchlebstwem, czczymi błyskawkami,

Ale rozumem, cnotą i rycerskim potem -

Tymi dobijano się serc damskich darami.

${ }^{17}$ W. I. Marewicz, Do Jaśnie Oświeconego Książęcia Jegomości Aleksandra na Drui, Różannej, Dereczynie, Wysokim Litewskim, Dombrownie, Bychowcach, Czerei, Szkudach etc., hrabiego Sapiehy, kanclerza W.W. X. litewskiego, kawalera orderów polskich, w: tegoż, Miłość dla cnoty. Komedia oryginalna w 3 aktach, drukarnia nadworska Jego Królewskiej Mości i Prześwietnej Komisji Edukacji Narodowej, Warszawa 1787, s. nlb.

${ }^{18}$ Tamże.

19 Tamże. 
Gdy względu na zwodnicze nie mając przyłudy,

Damy cnotę w mężczyznach tylko szacowały;

Kto większe dla ojczyzny zniósł prace i trudy,

Temu w nadgrodę rękę i serce dawały ${ }^{20}$.

Oprócz nawiązań do uniwersalnych cnót pokojowych i jednocześnie wartości z kręgu etosu rycerskiego w dedykacjach znajdujemy także osobiste refleksje autora, dotyczące jego niespełnionych pragnień, związanych z próbami ułożenia sobie życia z ukochaną kobietą oraz nieudanymi staraniami, których celem była poprawa warunków bytowych (między innymi dążenie do wykupu utraconego majątku i odzyskania dawnej, wyższej pozycji materialnej i społecznej).

Szczególnie wymowny w tym kontekście jest na przykład początek dedykacji do Karoliny Wołodkowiczowej z Brzostowskich w dramie Żona opuszczona na bezludnej wyspie, gdzie Marewicz dokonuje następującego porównania:

Dziełko moje [...] nosi tytuł na sobie: „Żona opuszczona na bezludnej wyspie”. Autor zaś jego może bardzo stosownie przybrać sobie tytuł: „Rodaka opuszczonego na ojczystej ziemi”. Historia, z której wzięta jest ta intryga, wystawuje nam żonę, opuszczoną od męża; historia autora ukazuje go zapomnianym od przyjaciół i uręczających mu przed tym swoją opiekę i pomoc. - Żona opuszczoną została od męża przez przypadek, autor zaś od krajowców zapomnianym został za ten grzech zapewne, że dbając więcej zawsze o imię poczciwego człeka, jak o los własny, nigdy nie był zdrajcą, oszukiwaczem, przedajnym, zwódcą, fałszerzem lub w jakimkolwiek sposobie szkodcą czyim. Ani chciał nigdy z poszarpanej sławy cudzej sklejać sobie honorowe tytuły lub z rozwalin cudzego szczęścia budować sobie fortunę ${ }^{21}$.

Uwagę zwraca uwydatniona tu analogia między losami bohaterki dramy a sytuacją autora, przy czym, dla nadania obiektywizmu słowom o własnej kondycji i wartościach, którymi kieruje się on w życiu, słowa te formułuje w trzeciej osobie. W ten sposób Marewicz niejako rezygnuje tu z ,ja” autorskiego, silnie zaznaczanego w innych cząstkach ram wydawniczych, jakie znajdujemy w jego publikacjach. Tak skonstruowany fragment dotyczący osoby autora zawiera oskarżenie społeczeństwa i zjawisk obyczajowo-moralnych, które doprowadziły go do gorzkiego stwierdzenia, iż został niesprawiedliwie opuszczony przez rodaków i państwo.

20 Tamże.

${ }^{21}$ W. I. Marewicz, Do Jaśnie Wielmożnej Jejm[oś]ci Pani Karoliny z Brzostowskich Wołodkowiczowej, starościny hajeńskiej i rotmistrzowej Kawalerii Narodowej, w: tegoż, Żona opuszczona na bezludnej wyspie. Drama w 1 akcie, z intrygi wziętej z opery włoskiej, Wilno 1795, s. A(a). 
Refleksjom osobistym towarzyszą wielokroć pochwały kierowane do adresatów dedykacji. Panegiryczne ujęcie postaci adresatów, charakterystyczne dla formuł dedykacyjnych i mające niejako charakter konwencjonalny, nie przeszkadza Marewiczowi wprowadzać do tych pochwał pierwiastków osobistych, cechujących się otwartością i szczerością.

Panegiryzm Marewicza w tych laudacjach jest często przesadny, lecz przecież dobrze zakorzeniony w tradycji literackiej. Oto próbka pochwalnego stylu poety, zabiegającego o opiekę wyżej wspomnianej Wołodkowiczowej. Autor, w zgodzie z konwencją, wylicza różnorodne zalety tej damy (uroda, wysokie urodzenie, bogactwo), ale ponad nie, $\mathrm{z}$ emocjonalnym zaangażowaniem, wysławia jej walory duchowe. Sygnalizuje też, że szczególnie owe cnoty są powodem podjętych przez niego starań o jej opiekę:

Piękność twoja, Pani, powszechnie chwalona jest darem losu. Rodowitość jest dziełem przypadku. Majątek jest owocem szczęścia. Dusza zaś tkliwa, umysł wspaniały, serce dobroczynne, sposób myślenia szlachetny, czyny cnotliwe i inne przymioty, czyniące zaszczyt płci niewieściej, są własnym twoim nabytkiem i twoją własnością do nikogo nienależną, z których cię ani nieprzyjaciel obedrzeć, ani przypadek wyzuć nie potrafi. I to, to jest, co mnie ośmieliło i dziełko to, i autora razem, poruczyć twojej opiece ${ }^{22}$.

W tych prośbach o opiekę i wstawiennictwo widzimy w Marewiczu człowieka, który doznał w życiu wielu niepowodzeń, po których trudno mu się podnieść, ma poczucie niesłusznego, niezasłużonego odtrącenia przez społeczeństwo. Najczęściej na końcu dedykacji podpisuje się jako „obowiązany” i „najniższy sługa”, co też było częścią tradycji (na przykład epistolarnej), lecz co w kontekście jego pełnych goryczy wyznań nabiera przejmującego wydźwięku. W zakończeniu dedykacji do Aleksandra Sapiehy w komedii Miłość dla cnoty pisarz porównuje siebie do „małej chróściny”. Wykorzystuje zarazem motyw wielkiego drzewa, osłaniającego swym dobroczynnym cieniem niewielką krzewinę (znany na przykład z poezji Adama Naruszewicza czy Franciszka Dionizego Kniaźnina):

Dzieło to razem z autorem, żądającym dozgonnie szczycić się Jaśnie Oświeconego [...] Mości Dobrodzieja opieką oddaję. Bo wszakże

Dlatego przyrodzenie dębiny ogromne

Umieściło pomiędzy małymi chróściny,

Aby onych gałęźmi, które są niezłomne,

${ }^{22}$ Tamże, s. A(b). 
Od wstrząsających wiatrów zasłonić krzewiny.

Dlatego i ja tobie oddaję się wiecznie,

Abym pod twoim cieniem mógł wzrastać bezpiecznie ${ }^{23}$.

Z kolei w dedykacji do arcybiskupa lwowskiego Kajetana Kickiego, zamieszczonej w edycji dramy Szczęście w nieszczęściu, pisarz widzi siebie jako mały strumyk, znajdujący zbawienne ujście w wielkiej wodzie:

Tyś człowiek. - I ja człowiek. - Te słodkie wspomnienie

Sprawuje milsze w duszy mej wyobrażenie.

Ja cierpię jak człek. - Ty zaś jak człek to uczujesz

I słabszemu pomocy swej nie pożałujesz.

Mały strumyk wciska się zawsze w wielką rzekę -

I ja biedny tulę się pod twoją opiekę ${ }^{24}$.

Natomiast w dedykacji do Wołodkowiczowej, we wspomnianej dramie Żona opuszczona na bezludnej wyspie, Marewicz zrównuje siebie z perzem, to jest z pogardzanym, lecz jednak użytecznym chwastem:

Nie racz więc garnących się do siebie odpychać! Bo to jest tylko własnością dusz wielkich - umacniać słabych i tulić do siebie biednych.

Czasem i to jest dobrym, co się zda ladaco.

Któż wie: może się i ja przydam jeszcze na co.

Bo wszak nie ma tak wyjałowiałej roli, żeby z siebie czego nie rodziła. Sam perz po polach rozłażący się i one głuszący, przydatny jest i ubogim ludziom do żywienia się, i aptekarzom do dekoktów krew czyszczących ${ }^{25}$.

Inne typy wypowiedzi ramowej zawiera opera Marewicza Polusia córka kotodzieja, czyli Wolność oswobodzona. Opera tragiczna w dwóch aktach, z rosyjskiego na język polski przettumaczona (wydana anonimowo dwukrotnie: b.m. 1789 i we Lwowie 1791). Jest to utwór polityczno-okolicznościowy o wymowie alegorycznej. Głównymi bohaterami sztuki są: dziedzic dóbr nazywających się Wolność, w opiece będący - Swobodzki, czyli król Stanisław August Poniatowski; opiekująca się Swobodzkim - Przemocka, czyli carowa Katarzyna II oraz pokojowa u Przemockiej - Polusia, to jest Polska. Aleksandrowska określa tę ope-

${ }^{23}$ W. I. Marewicz, Do Jaśnie Oświeconego..., s. nlb.

${ }^{24}$ W. I. Marewicz, Do Jaśnie Wielmożnego J[ego]M[ości] księdza Kajetana Ignacego Gozdawy na Kitkach Kickiego, arcybiskupa lwowskiego, w: tegoż, Szczęście w nieszczęściu, czyli Wzór stałości ludzkości i cierpliwości. Drama oryginalne w 4 aktach, b.m.w. 1798, s. nlb.

${ }^{25}$ W. I. Marewicz, Do Jaśnie Wielmożnej..., s. A(b). 
rę jako „udramatyzowany traktat polityczny”26, z kolei Ryszard Łużny nazywa ją „scenicznym pamfletem wymierzonym przeciwko polityce Rosji w stosunku do Polski”27. Warto zaznaczyć, że sztukę tę, ze względu na aktualny, polityczny charakter i antyrosyjską wymowę, przypisywano Julianowi Ursynowi Niemcewiczowi (notabene ta mylna atrybucja autorska stanowi potwierdzenie wartości artystycznej utworu).

Na karcie tytułowej wspomnianej wyżej opery Marewicz umieścił cytat zapożyczony z jednego z utworów Ignacego Krasickiego (XXV. Do...:), pomieszczonych w zbiorze Wierszy z proza (powstałym przed 1788 rokiem):

Sławny triumf, co zadziwia,

Większy ten, co uszczęśliwia ${ }^{28}$.

Co ważne, Marewicz nie kryje autora cytowanego przez siebie dwuwiersza, podając nazwisko Krasickiego.

Polusia córka kołodzieja, czyli Wolność oswobodzona zawiera jeszcze jeden ważny element ramy utworu, mianowicie przedmowę Do Czytelnika. Tekst ten nie jest obszerny, ma bowiem objętość jednej strony ${ }^{29}$. Już na wstępie pisarz wyjaśnia, dlaczego odwołał się do Krasickiego i nie ukrył autorstwa „księcia poetów”:

Kładzie się zaś to wielkie imię z tych dwóch przyczyn: raz, że mu w tym czasie cała powszechność winna jest bardzo wiele, drugi, aby to pismo, w odstępnym

${ }^{26}$ E. Aleksandrowska, Wincenty Ignacy Marewicz..., s. 335.

${ }^{27}$ R. Łużny, Bohomolec i Bogustawski w Rosji. (Z dziejów powiązań literackich polsko-rosyjskich doby Oświecenia), „Slavia Orientalis” 1961, nr 2, s. 147.

${ }^{28}$ W. I. Marewicz, Polusia córka kołodzieja, czyli Wolność oswobodzona. Opera tragiczna w dwóch aktach, z rosyjskiego na język polski przetlumaczona, Lwów 1791 (karta tytułowa).

Por. cytat z I. Krasickiego: Wiersze z proza, XXV. Do...:

Szczęście to jest dla narodu, kiedy nauki kwitną, a uczeni są w poważaniu.

Szabla kraje rozpościera,

Ale pióro je istoczy,

Moc dzierży, wzmacnia, zabiera,

Lecz rozum otwarza oczy.

Slawny tryumf, co zadziwia,

Większy ten, co uszczęśliwia.

A jest w dobroci rządzących, w szczęściu rządzonych.

(I. Krasicki, Pisma poetyckie, oprac. Z. Goliński, t. II, Państwowy Instytut Wydawniczy, Warszawa 1976, s. 68; podkr. - A.P.).

${ }^{29}$ Co ciekawe, Karol Estreicher w swojej bibliografii przy operze Marewicza dodaje: „Przy jednym egzemplarzu widziałem obszerną samochwalczą przedmowę, ale tej w innych znanych nie ma. Przedmowa ta godna byłaby przedruku, tak jest jowialna. Niestety, póki co, nie udało mi się do tego «arcyciekawego» tekstu dotrzeć". Zob. K. Estreicher, Bibliografia polska, cz. III, t. XI (M-My), Akademia Umiejętności (drukarnia Uniwersytetu Jagiellońskiego), Kraków 1908, s. 151. 
nieco od oryginału tłumaczeniu, gdy go subtelni Zoilowie wyszperać raczą, powagą najprzyzwoitszego imieniowi temu szacunku, od ich uszczypliwych ukąsków zratowane być mogło ${ }^{30}$.

W zakończeniu pisarz ponownie odwołuje się do Krasickiego: „A teraz przedmowę kończę słowami autora Monomachii: «Czytaj i dozwól niech czytają twoi»"31.

W tej interesującej cząstce ramy wydawniczej Polusi... Marewicz ponadto przyznaje się czytelnikowi do problemów i trudności, jakie miał podczas tłumaczenia utworu:

Godzi się atoli wyznać prawdę, że w wielu miejscach znajdzie może Czytelnik i znaczne omyłki, ile gdy wiadomością swoją zechce się zbliżyć aż do samego oryginału, lecz niedostateczna biegłość w języku zagranicznym, powinna się wziąć za ekskuzę mylnego tłumaczenia. - Że zaś niektóre sceny zdają się być przydługie na sposób pisania dzieł w tej naturze, niech i to łaskawy Czytelnik nie bierze za winę tłumacza, gdyż one tak się w oryginalnym znajdują egzemplarzu; zmniejszać je lub przedzielać, byłoby to jedno, co chcieć w cudzą się ubrać suknię, a do stanu niezrobioną. - Trzeci akt opuścił się, bo dla alegorycznych i trudnych słów w tamtym języku, ani było można tak prędko i łatwo dociec tego, co autor w sensie głęboki, a w przeniknieniu trudny, starał się tym aktem okazaćs ${ }^{32}$.

Zwraca uwagę wyjątkowa szczerość tego wyznania, jednak opera ta nie była wcale tłumaczeniem z języka rosyjskiego, jak Marewicz sugeruje, a wręcz odwrotnie - w roku 1794 (trzy lata po ukazaniu się drugiej edycji Polusi...) sztukę Marewicza na język rosyjski przetłumaczył Wasilij Anastasiewicz (albo Bazyli Anastasewicz - jak podpisywał się w listach do Polaków). Przed laty rosyjski literaturoznawca, Paweł Bierkow, odnalazł pośród rękopisów Biblioteki im. Sałtykowa-Szczedrina w Petersburgu (wówczas w Leningradzie) sztukę Polusia, docz

\footnotetext{
${ }^{30}$ W. I. Marewicz, Do czytelnika, w: tegoż, Polusia..., s. nlb.

${ }^{31}$ Tamże, s. nlb.

Por. cytat z I. Krasickiego (Monomachia, pieśń 6, w. 113-120):

Czytaj i pozwól - niech czytają twoi,

Niech się z nich każdy niewinnie rozśmieje.

Żaden nagany sobie nie przyswoi,

Nikt się nie zgorszy, mam pewną nadzieję.

Prawdziwa cnota krytyk się nie boi,

Niechaj występek jęczy i boleje.

Winien odwołać, kto zmyśla zuchwale:

Przeczytaj - osądź; nie pochwalisz - spalę.

(I. Krasicki, Pisma ..., t. I, s. 119; podkr. - A.P.).

${ }^{32}$ Tamże, s. nlb.
} 
kolesnika, ili oswobożdionnaja wolnost'. Opiera tragiczeskaja $w 2$ diejstwijach. Pieriewod s polskogo $W$. Anastasiewicza ${ }^{33}$. Przekład rosyjski nigdy nie ukazał się w druku, natomiast rękopis znajduje się do dziś we wspomnianej bibliotece.

Widzimy zatem, że i tytuł opery, i poprzedzająca utwór przedmowa Marewicza były przemyślanym, taktycznym kamuflażem, celem ukrycia drażliwych politycznych treści.

Jeśli chodzi o epigrafy, to w utworach dramatycznych Marewicza pojawia się jeszcze jeden, ale poprzedzający nie całe dzieło, a dedykację. Mowa o dramie Szczęście w nieszczęściu, w której dedykację do Kajetana Kickiego rozpoczyna dwuwiersz:

Kto czyni co może, ten czyni dość wiele.

Ja, zrobiwszy, co mogłem, poświęcam ci śmiele ${ }^{34}$.

Wincenty Marewicz jest także autorem zbioru przysłów, w którym znajdujemy nieco inną wersję pierwszego wersu wspomnianego epigramatu, mianowicie: „Wiele czyni, kto czyni, co może”35. Warto zaznaczyć, że ten zwrot został dodany do Nowej księgi przystów i wyrażeń przystowiowych polskich jako odmiana przysłowia: „Dość z siebie czyni, kto wykona, co może”36.

Swoje dzieła Marewicz wydawał własnym kosztem, a po opublikowaniu rozsyłał znanym osobistościom i przyjaciołom, bądź wręcz narzucał się ze sprzedażą swoich utworów, roznosząc ich egzemplarze po domach ${ }^{37}$. Można powiedzieć, że pisarz uprawiał swego rodzaju marketing literacki. Również w druku Marewicz dbał o autoreklamę. Zapewne nie bez przyczyny już na kartach tytułowych swoich dzieł informował czytelników o tym, że utwory te były wystawiane w teatrach. Oto kilka przykładów: Żona opuszczona na bezludnej wyspie. Drama w 1 akcie, $z$ intrygi wziętej z opery włoskiej, napisana przez W. Marewicza roku 1795 w Wilnie i tegoż roku na wileńskim teatrze grana dnia 19. kwietnia (Wilno 1795), Miłość wszystkich porównywa. Komedia oryginalna w 5 aktach przez W. Marewicza rotmistrza województwa trockiego napisana, po kilkakroć na teatrach warszawskim, lwowskim i wileńskim grana (Wilno 1796) albo Wszystko się skończyło na projekcie. Komedia oryginalna we 2 aktach, napisana przez W. Marewicza w roku 1795, w tymże roku dnia 26 kwietnia grana na teatrze wileńskim (b.m.r.).

${ }^{33}$ Por. S. Nikołajew, Polsko-rosyjskie zwiazki literackie w epoce Stanisława Augusta Poniatowskiego, „Ruch Literacki” 2003, z. 1 (256), s. 2.

${ }^{34}$ W.I. Marewicz, Do Jaśnie Wielmożnego..., s. nlb.

${ }^{35}$ Tenże, Przysłowia i maksymy, Drukarnia Misjonarzy, Warszawa 1788, s. A(1).

${ }^{36}$ Zob. hasło „Czynić” (23), w: Nowa księga przysłów i wyrażeń przysłowiowych polskich, t. I, red. J. Krzyżanowski, Państwowy Instytut Wydawniczy, Warszawa 1969, s. 395.

${ }^{37}$ Mowa o tym m.in. w: E. Tyszkiewicz, Wincenty Marewicz, nr 63, s. 3; E. Aleksandrowska, Marewicz Wincenty Ignacy, s. 634. 
Dodajmy, że funkcję zalecającą pełniły także zapowiedzi wydawnicze lub spis dzieł Marewicza, które już zostały opublikowane. Na końcu dramy Szczęście $w$ nieszczęściu znajdujemy inny jeszcze składnik ramy edytorskiej, mianowicie Rejestr różnych $i$ w różnych miejscach drukowanych dziet Jegomości Pana Marewicza $z$ wyrażeniem ich ceny. Utwory dramatyczne zostały tu podane osobno. Łącznie rejestr ten zawiera dwadzieścia sześć tytułów. Fakt, iż w spisie znajdują się utwory, które wydrukowano w różnych wydawnictwach, może potwierdzać przypuszczenie, że dodanie tego rejestru było ideą samego autora, a nie wydawcy tego utworu ${ }^{38}$.

Wincenty Ignacy Marewicz przez ówczesnych i niektórych badaczy późniejszych uważany był najczęściej za dziwaka, grafomana i wierszokletę. Dopiero w drugiej połowie XX wieku doczekał się słów uznania. Akcentowano między innymi, że był on w swej twórczości bliski sentymentalizmowi Jana Jakuba Rousseau jako autora Wyznañ ${ }^{39}$. Autor z pewnością należy do grupy literatów drugorzędnych, jednak jego biografia i twórczość dokumentują i ujawniają wyrazistsze losy tegoż pisarza niż ówczesnych twórców wybitnych. Ponadto w jego różnorodnym dorobku (mało dotychczas zbadanym) są utwory interesujące i udane artystycznie, a zatem warte rozpoznania i omówienia w pracach poświęconych historii literatury polskiego oświecenia.

Problemowi ramy wydawniczej utworów Marewicza również do tej pory nie poświęcano uwagi. Zagadnienie to wymaga szerszego ujęcia badawczego, gdyż prawie wszystkie tomiki tego niedocenionego pisarza zawierają jakieś typy wypowiedzi ramowych, zarówno tych stanowiących introdukcję, jak i zamknięcie dzieła (dedykacje, przedmowy, epigrafy, motta, winiety, monogramy, zapowiedzi wydawnicze, spisy utworów już wydanych itp.). W różnorodnych cząstkach ramy wydawniczej utworów (zwłaszcza w preliminariach) Marewicz pisze o swoich zagmatwanych kolejach losu, nie ukrywa własnych niepowodzeń i błędów. Niejednokrotnie zatem w tych formalnych, zdawałoby się, elementach wyposażenia książek sygnowanych jego nazwiskiem, kryją się ważne informacje o twórcy, jego dziele i życiu. W dedykacjach i przedmowach autor jest niezwykle otwarty i szczery (podobnie jak w utworach stricte literackich). Tę cechę (notabene różnie ocenianą) podkreślali nie tylko badacze epoki stanisławowskiej, którzy niejako przy okazji sygnalizowali obecność Marewicza w życiu literackim i teatralnym tego okresu, lecz również akcentowała to Elżbieta Aleksandrowska. Opracowaniom wrocławskiej badaczki poświęconym Wincentemu Ignacemu Marewiczowi w dużej mierze zawdzięczamy impuls - zachętę do dalszego badania i edytowania twórczości tego „chudego literata”.

\footnotetext{
${ }^{38}$ Zob. W. I. Marewicz, Szczęście w nieszczęściu..., s. 187-189.

${ }^{39}$ Por. np.: J. Jackl, dz. cyt., s. 426; E. Aleksandrowska, Wincenty Ignacy Marewicz..., s. 332, 340.
} 


\section{Bibliografia}

\section{Podmiotowa}

Marewicz Wincenty Ignacy, Dorywcze zabawki wierszem i proza, Drukarnia Misjonarzy, Warszawa 1788.

Marewicz Wincenty Ignacy, Do Jaśnie Oświeconego Książęcia Jegomości Aleksandra na Drui, Różannej, Dereczynie, Wysokim Litewskim, Dombrownie, Bychowcach, Czerei, Szkudach etc., hrabiego Sapiehy, kanclerza W.W.X. litewskiego, kawalera orderów polskich, w: tegoż, Miłość dla cnoty. Komedia oryginalna $w 3$ aktach, drukarnia nadworska Jego Królewskiej Mości i Prześwietnej Komisji Edukacji Narodowej, Warszawa 1787.

Marewicz Wincenty Ignacy, Do Jaśnie Wielmożnego J[ego]M[ości] księdza Kajetana Ignacego Gozdawy na Kitkach Kickiego, arcybiskupa lwowskiego, w: tegoż, Szczęście w nieszczęściu, czyli Wzór stałości ludzkości i cierpliwości. Drama oryginalne w 4 aktach, b.m.w. 1798.

Marewicz Wincenty Ignacy, Do Jaśnie Wielmożnej Jejm[oś]ci Pani Karoliny z Brzostowskich Wołodkowiczowej, starościny hajeńskiej i rotmistrzowej Kawalerii Narodowej, w: tegoż, Żona opuszczona na bezludnej wyspie. Drama w 1 akcie, z intrygi wziętej z opery włoskiej, Wilno 1795.

Marewicz Wincenty Ignacy, Ostatnia do Laury odezwa wierszem i proza, Drukarnia Misjonarzy, Warszawa 1788 .

Marewicz Wincenty Ignacy, Polusia córka kołodzieja, czyli Wolność oswobodzona. Opera tragiczna $w$ dwóch aktach, z rosyjskiego na język polski przettumaczona, Lwów 1791.

Marewicz Wincenty Ignacy, Przysłowia i maksymy, Drukarnia Misjonarzy, Warszawa 1788.

Marewicz Wincenty Ignacy, Zdarzenia czyli sny... wierszem i proza, t. 1-2, Drukarnia P. Dufour, Warszawa 1786-1787.

\section{Przedmiotowa}

Aleksandrowska Elżbieta, Marewicz Wincenty Ignacy (1755-1822), w: Dawni pisarze polscy od początków piśmiennictwa do Młodej Polski. Przewodnik biograficzny i bibliograficzny, red. działu Literatura oświecenia: E. Aleksandrowska, koordynator całości: R. Loth, t. II (I-Me), Wydawnictwa Szkolne i Pedagogiczne, Warszawa 2001, s. 427-429.

Aleksandrowska Elżbieta, Marewicz Wincenty Ignacy, w: Polski słownik biograficzny, t. XIX, Zakład Narodowy im. Ossolińskich - Wydawnictwo Polskiej Akademii Nauk, Wrocław-Warszawa-Kraków-Gdańsk 1974, s. 633-636.

Aleksandrowska Elżbieta, Wincenty Ignacy Marewicz (1755-1822), w: Pisarze polskiego oświecenia, pod red. T. Kostkiewiczowej i Z. Golińskiego, t. 2, Państwowe Wydawnictwo Naukowe, Warszawa 1994, s. 332-341.

Aleksandrowska Elżbieta, „Zabawy Przyjemne i Pożyteczne” 1770-1777. Monografia bibliograficzna, Wydawnictwo Instytutu Badań Literackich PAN, Warszawa 1999.

Bibliografia literatury polskiej „Nowy Korbut”, t. V: Oświecenie, oprac. E. Aleksandrowska z zespołem, Państwowy Instytut Wydawniczy, Warszawa 1966-1972.

Borkowski Andrzej, Konteksty interpretacyjne literackiej ramy wydawniczej „,Ogrodu nie plewionego” Wacława Potockiego, „Slavica Litteraria” 13, 2010, nr 1-2, s. 63-72.

Cztery wieki fraszki polskiej, wybór i wstęp J. Tuwim, Czytelnik, Warszawa 1957.

Estreicher Karol, Bibliografia polska, cz. III, t. XI (M-My), Akademia Umiejętności (drukarnia Uniwersytetu Jagiellońskiego), Kraków 1908.

Jackl Jerzy, Litteraria, w: Teatr Narodowy 1765-1794, red. J. Kott, Państwowy Instytut Wydawniczy, Warszawa 1967, s. 425-426.

Kaleta Roman, Miejsce i społeczna funkcja literatów w okresie Oświecenia, w: Problemy literatury polskiej okresu Oświecenia, red. Z. Goliński, Zakład Narodowy im. Ossolińskich, Wrocław 1973, s. 5-47.

Krasicki Ignacy, Pisma poetyckie, oprac. Z. Goliński, t. II, Państwowy Instytut Wydawniczy, Warszawa 1976. 
Lipatow Aleksander Władimirowicz, Poczatki polskiej prozy preromantycznej XVIII wieku (Ewolucja myśli artystycznej oraz przemiany gatunkowe na tle narodowego i europejskiego procesu literackiego), tłum. Jolanta Aulak, Magdalena Dobrogoszcz, „Przegląd Humanistyczny" 1998, nr 1, s. 80-102.

Липатов Александр Владимирович, Начала польской предромантической прозы XVIII в. (Эволюиия художественного мышления и внутрижанровые изменения в контексте национального и общеевропейского литературного прочесса), w: Развитие прозачческих жанров в литературах стран Центральной и Юго-Восточной Европь, ред. И. И. Калиганов, А.П. Соловьева, Б. Ф. Стахеев, Наука, Москва 1991, s. 58-84.

Łużny Ryszard, Bohomolec i Bogusławski w Rosji. (Z dziejów powiąań literackich polsko-rosyjskich doby Oświecenia), „Slavia Orientalis” 1961, nr 2, s. 147-166.

Mazurkowa Bożena, Literacka rama wydawnicza dzieł F.D. Kniaźnina (na tle porównawczym), Wydawnictwo Uniwersytetu Śląskiego, Katowice 1993.

Mazurkowa Bożena, O reklamie wydawniczej w przedmowach edytorów i drukarzy polskich doby oświecenia, „Prace Naukowe Uniwersytetu Śląskiego. Studia Bibliograficzne” 5, 1992, s. 129-149.

Mazurkowa Bożena, Przedmowy, dedykacje i noty twórczości F. D. Kniaźnina, w: O literackiej ramie wydawniczej w ksiązkach dawnych, red. R. Ocieczek, Wydawnictwo Uniwersytetu Śląskiego, Katowice 1990, s. 63-98.

Mazurkowa Bożena, Tradycja i nowatorstwo w kształtowaniu literackiej ramy wydawniczej dziet F.D. Kniaźnina, „Prace Literackie”, seria XXXI, Wrocław 1991, s. 243-259.

Mazurkowa Bożena, ,Weksle prawdy i nieprawdy”. Studia literackie o książce oświeceniowej, Instytut Badań Literackich PAN, Warszawa 2011.

Naruszewicz Adam Stanisław, Poezje zebrane, wyd. B. Wolska, t. III, Instytut Badań Literackich PAN Wydawnictwo, Warszawa 2012, Biblioteka Pisarzy Polskiego Oświecenia, t. 11.

Nikołajew Siergiej, Polsko-rosyjskie zwiazki literackie w epoce Stanisława Augusta Poniatowskiego, ,Ruch Literacki” 2003, z. 1 (256), s. 1-8.

Norkowska Aleksandra, Codzienne zapachy miasta utrwalone w piśmiennictwie polskiego Oświecenia, w: Codzienność i niecodzienność oświeconych, t. II, W rezydencji, w podróży i na scenie publicznej, pod red. B. Mazurkowej, z udziałem M. Marcinkowskiej i S. P. Dąbrowskiego, Wydawnictwo Uniwersytetu Śląskiego, Katowice 2013, s. 115-125, Prace Naukowe Uniwersytetu Śląskiego w Katowicach nr 3072.

Nowa księga przysłów i wyrażeń przysłowiowych polskich, t. I, red. J. Krzyżanowski, Państwowy Instytut Wydawniczy, Warszawa 1969.

Ocieczek Renarda, O przedmowach w polskich ksiażkach barokowych, w: Przedmowa w książce dawnej $i$ współczesnej, pod red. tejże, przy współudziale R. Ryby, Wydawnictwo Gnome, Katowice 2002, s. 102-116.

Ocieczek Renarda, O różnych aspektach literackiej ramy wydawniczej w książkach dawnych, w: O literackiej ramie wydawniczej w ksiązkach dawnych, pod red. tejże, Wydawnictwo Uniwersytetu Śląskiego, Katowice 1990, s. 7-19.

Ocieczek Renarda, O staropolskich tekstach dedykacyjnych. Uwagi wstępne, w: Dedykacje w ksiażce dawnej $i$ wspótczesnej, red. R. Ocieczek i A. Sitkowa, Wydawnictwo Gnome, Katowice 2006, s. 7-10.

Ocieczek Renarda, hasło: Rama utworu, w: Stownik literatury staropolskiej. (Średniowiecze - Renesans - Barok), red. T. Michałowska przy współudziale B. Otwinowskiej, E. Sarnowskiej-Temeriusz, Zakład Narodowy im. Ossolińskich, Wrocław 1990, s. 684-688.

Ocieczek Renarda, Studia o dawnej książce, Wydawnictwo Gnome, Katowice 2002.

Petlak Anna, Miłosne ,odezwy” do Laury Wincentego Ignacego Marewicza, w: Codzienność i niecodzienność oświeconych, t. I, Przyjemności, pasje, upodobania, pod red. B. Mazurkowej, z udziałem M. Marcinkowskiej i S.P. Dąbrowskiego, Wydawnictwo Uniwersytetu Śląskiego, Katowice 2013, s. 191-201, Prace Naukowe Uniwersytetu Śląskiego w Katowicach nr 3072. 
Pirecki Piotr, Z problematyki ramy literackiej w komediach plebejskich XVII w. (wybrane zagadnienia), „Acta Universitatis Lodziensis. Folia Litteraria Polonica” 2002, z. 5, s. 13-26.

Ratajczakowa Dobrochna, Komedia oświeconych 1752-1795, Państwowe Wydawnictwo Naukowe, Warszawa 1993.

Rysztowski Piotr, Jak napisać historię grafomanii, „Teksty Drugie” 2012, nr 6, s. 346-357.

Świat poprawiać - zuchwałe rzemiosło. Antologia poezji polskiego Oświecenia, oprac. T. Kostkiewiczowa, Z. Goliński, Państwowy Instytut Wydawniczy, Warszawa 1981.

Tutak Kinga, Dedykacja w świetle genologii lingwistycznej, „LingVaria” 2010, nr 1 (9); s. 125-135.

Tyszkiewicz Eustachy, Wincenty Marewicz. Studium obyczajowe, Drukarnia „Gazety Warszawskiej”, Warszawa 1870.

Tyszkiewicz Eustachy, Wincenty Marewicz, „Gazeta Warszawska” 1870, nr 61, s. 3-4; nr 62, s. 3; nr 63, s. 3.

Wiersze imieninowe poetów z drugiej połowy XVIII wieku, wstęp, wybór tekstów i opracowanie B. Wolska, B. Mazurkowa, T. Chachulski, Instytut Badań Literackich PAN, Warszawa 2011.

Wiersze polityczne Sejmu Czteroletniego, cz. 1 (1788-1789), oprac. K. Maksimowicz, Wydawnictwo Sejmowe, Warszawa 1998.

Anna Petlak

\section{Contribution to the study of the publishing framework of dramatic works written by Wincenty Ignacy Marewicz}

(Summary)

The paper aims to promote a neglected, and consequently little-known, writer of the period of the Polish Enlightenment - Wincenty Ignacy Marewicz (1775-1822), the author of, among others, poems, writings in verse and prose, a collection of sayings, as well as comedies, dramas and an opera.

The publication discusses some of the elements of the publishing framework (including dedications, prefaces, epigraphs, and lists of works already published) which the writer used in his dramatic works and which include important information about him, his work and life.

The paper is a kind of reconnaissance to pave the way for further research on the above-mentioned subject.

Keywords: Polish Enlightenment literature; publishing framework; Wincenty Ignacy Marewicz; dramatic works; Renarda Ocieczek

Słowa kluczowe: literatura polskiego oświecenia; rama wydawnicza; Wincenty Ignacy Marewicz; dramat; Renarda Ocieczek 